\title{
KDM4C Gene
}

National Cancer Institute

\section{Source}

National Cancer Institute. KDM4C Gene. NCI Thesaurus. Code C148356.

This gene is involved in histone $\mathrm{H} 3$ demethylation. 